\section{Effect of Substrate Stratification on Growth of Common Nursery Weed Species and Container-grown Ornamental Species}

\author{
Yuvraj Khamare $^{1}$, S. Christopher Marble ${ }^{1}$, James E. Altland ${ }^{2}$, \\ Brian J. Pearson ${ }^{1}$, Jianjun Chen ${ }^{1}$, and Pratap Devkota ${ }^{3}$
}

ADDITIONAL INDEX WORDs. bittercress, blue plumbago, ligustrum, liverwort, substrate composition, weed management

SumMARY. Substrate stratification is a method of filling nursery containers with "layers" of different substrates, or different textures of the same substrate. Recently, it has been proposed as a means to improve drainage, substrate moisture dynamics, and optimize nutrient use efficiency. Substrates layered with larger particle bark as the top portion and smaller particle bark as the bottom portion of the container profile would theoretically result in a substrate that dries quickly on the surface, thereby reducing weed germination, but that would also retain adequate moisture for crop growth. The objective of this study was to evaluate the effect of stratified substrates on the growth of common nursery weeds and ornamental crops. This study evaluated the use of coarser bark ( $<0.5$ or 0.75 inches) as the top substrate and finer bark ( $<0.38$ inches) as the bottom substrate with the goal of reducing the water-holding capacity in the top 2 to 3 inches of the substrate to reduce weed germination and growth. Results showed that substrate stratification with more coarse bark on the top decreased the growth of bittercress (Cardamine flexuosa) by $80 \%$ to $97 \%$, whereas liverwort (Marchantia polymorpha) coverage was reduced by $95 \%$ to $99 \%$. Substrate stratification initially reduced the growth of ligustrum (Ligustrum japonicum) and blue plumbago

(Plumbago auriculata), but there was no difference in the shoot or root dry weights of either species in comparison with those of nonstratified industry standard substrates at the end of 24 weeks. The data suggest substrate stratification could be used as an effective weed management strategy for container nursery production.

$\mathrm{W}$ eed control costs can exceed $\$ 10,000$ per acre and is considered one of the most costly and challenging aspects of pest management in nursery production (Ingram et al., 2016, 2017). Challenges to weed management in container nurseries include the lack of labeled postemergence herbicide options, intense weed competition, heavy

Received for publication 4 Oct. 2021. Accepted for publication 30 Nov. 2021.

Published online 19 January 2022

${ }^{1}$ Environmental Horticulture Department, Mid-Florida Research and Education Center, Institute of Food and Agricultural Sciences, University of Florida, 2725 South Binion Road, Apopka, FL 32703

${ }^{2}$ U.S. Department of Agriculture, Application Technology Research Unit, 1680 Madison Avenue, Wooster, OH 44691

${ }^{3}$ Agronomy Department, West Florida Research and Education Center, Institute of Food and Agricultural Sciences, University of Florida, 4253 Experiment Road, Highway 182, Jay, FL 32565

S.C.M. is the corresponding author. E-mail: marblesc@ufl.edu.

This is an open access article distributed under the CC BY-NC-ND license (https://creativecommons. org/licenses/by-nc-nd/4.0/).

https://doi.org/10.21273/HORTTECH04965-21 reliance on hand weeding, and high crop species diversity (Case et al., 2005). Because of limited or confined nutrient availability and water availability within nursery containers, many weed species can reduce ornamental crop growth by $\geq 60 \%$ and lead to an increase in production time (BerchielliRobertson et al., 1990). Although not all weed species are competitive with ornamentals, weed presence thresholds remain low because of marketability concerns (Simpson et al., 2002).

Weeds in most ornamental crops can be successfully managed with regular preemergence herbicide applications paired with hand weeding (Case et al., 2005; Gilliam et al., 1990). However, there are several negative consequences associated with frequent use of preemergence herbicides, including high costs (Stewart et al., 2017), potential leaching, runoff, or related concerns when recycling irrigation water (Poudyal and Cregg, 2019; Wilson et al., 1995). Additionally, it is inefficient because up to $80 \%$ of the applied herbicide fails to reach the container substrate surface, where it is needed for weed control (Gilliam et al., 1992). For many growers, the primary concern related to preemergence herbicides is crop safety because even minor damage can increase production times by months. The nursery industry produces thousands of different plant products, and there is no herbicide labeled for use on all species or, in many instances, not all varieties within a species. Additionally, many of the most popular tropical plants, succulents, herbaceous annuals, and perennials are highly sensitive to herbicides. For example, hydrangea (Hydrangea sp.) plants are grown throughout most of the United States, representing more than $\$ 106$ million per year in sales (U.S. Department of Agriculture, National Agricultural Statistics Service, 2019). However, they are highly prone to herbicide injury and have few labeled options. In addition, no preemergence herbicides are labeled for application in enclosed structures such as hoop houses or retractable-roof greenhouses. Because of these challenges, there is a need for more integrated weed management strategies that would help nursery growers reduce the cost of hand weeding and decrease the need for herbicide use.

Recent review articles have highlighted the use and efficacy of nonchemical control options such as weed discs, mulch, subsurface irrigation, and other strategies (Case et al., 2005; Stewart et al., 2017). Fertilizer placement is a strategy that has received attention in

\begin{tabular}{llll}
\hline $\begin{array}{l}\text { Units } \\
\text { To convert U.S. to SI, } \\
\text { multiply by }\end{array}$ & U.S. unit & SI unit & $\begin{array}{l}\text { To convert SI to U.S., } \\
\text { multiply by }\end{array}$ \\
\hline 0.4047 & acre(s) & ha & 2.4711 \\
0.3048 & $\mathrm{ft}$ & $\mathrm{m}$ & 3.2808 \\
3.7854 & gal & $\mathrm{L}$ & 0.2642 \\
2.54 & inch(es) & $\mathrm{cm}$ & 0.3937 \\
25.4 & inch(es) & $\mathrm{mm}$ & 0.0394 \\
6.4516 & inch & $\mathrm{cm}^{2}$ & 0.1550 \\
28.3495 & $\mathrm{oz}$ & $\mathrm{g}$ & 0.0353 \\
$\left({ }^{\circ} \mathrm{F}-32\right) \div 1.8$ & ${ }^{\circ} \mathrm{F}$ & ${ }^{\circ} \mathrm{C}$ & $\left({ }^{\circ} \mathrm{C} \times 1.8\right)+32$ \\
& & &
\end{tabular}


recent years. Because most nursery substrates comprising bark, peat, perlite, or sand have limited inherent nutrient content (especially plant-available nitrogen), controlled-release fertilizer (CRF) is often used as the primary fertilizer source to supply nutrients needed for crop growth. Typically, these fertilizers are applied via incorporation (homogeneously blending fertilizer throughout the substrate before planting) or topdressing (placing the entire allotment of fertilizer on the container substrate surface after planting), both of which allow weed seedlings access to nutrients on germination, often increasing weed growth to a greater degree than the crop (Blackshaw et al., 2004; Fain et al., 2003).

Strategic fertilizer placement such as subdressing involves filling the containers with $50 \%$ to $75 \%$ of the potting substrate, adding fertilizer in a single layer, placing the plant liner, and filling the remaining container volume with the same substrate (Khamare et al., 2020; Saha et al., 2019). This results in the top portion of the container substrate ( $\geq 1-4$ inches depending on liner size) without fertilizer. At least initially, germinating weed seedlings cannot access nutrients but the ornamental crop can because of the placement of the liner root ball in relation to the fertilized layer. Subdressing has been shown to reduce the growth of common nursery weeds such as spotted spurge (Euphorbia maculata) and eclipta (Eclipta prostrata) by more than $80 \%$ (Saha et al., 2019; Stewart et al., 2018). Additionally, it has resulted in similar or greater growth of many ornamental species when compared with the industry standard topdressing or incorporation methods (Altland et al., 2004; Khamare et al., 2020; Marble et al., 2012) because of increased crop competitive ability (Nkebiwe et al., 2016). Other strategic placements such as dibbling (placing fertilizer directly beneath the plant root ball) have also shown the ability to reduce weed growth by more than 90\% (Altland et al., 2004; Fain et al., 2003), but it has been associated with phytotoxicity or reduced crop growth in certain instances (Bir and Zondag, 1986).

Substrate stratification, or layering substrates, is a new area of research and is a form of substrate engineering whereby different substrates, or different textures of the same substrate, are used within a single container (Fields et al., 2021). The current industry practice is to fill the entire container with the same substrate, resulting in the bottom portion of the container retaining more water than the top portion, requiring a higher irrigation amount or more frequent watering to provide sufficient moisture for crop plants during establishment (Fields et al., 2020, 2021; Owen and Altland, 2008). Substrate physical properties such as air space (AS) and water-holding capacity are correlated with substrate particle size, with increasing water-holding capacity and decreasing AS as particle size decreases, directly impacting moisture levels within the container (Gruda and Schnitzler, 2004; Puustjarvi and Robertson, 1975; Richards et al., 1986). Fields et al. (2021) showed that by placing substrates with a high level of moisture and nutrient retention capacity on top of a coarse, freely draining substrate, fertilizer rates could be reduced by $20 \%$, with no negative effects on the growth or quality of 'Megalpio' (Red Drift $^{\circledR}$ ) roses (Rosa) compared with an industry standard substrate.

Although stratified substrates have been shown to result in improvements in terms of reduced fertilizer or more efficient utilization of irrigation, stratification described by Fields et al. (2021) could be applied inversely to provide a weed control benefit. Use of larger particles forming a freely draining substrate as the top strata containing no fertilizer and a fine-textured, highly moistureretentive substrate as the bottom, stratification could combine two of the most effective nonchemical weed management techniques: strategic fertilizer placement and a mulch-like layer that holds less moisture where weed seeds will be introduced. A prerequisite of seed germination is imbibition (Harper and Benton, 1966). Substrate stratification could be used as a means of reducing the water-holding capacity of the substrate at the top layer of the container, thus reducing the chances of weed seed germination, at least for some species. Additionally, a container substrate surface with a larger particle size could cause weed seeds to be flushed deep into the substrate, thus reducing or eliminating germination because many weeds require light to germinate (Keddy and Constabel, 1986). Research has shown that the growth of common nursery weeds such as pearlwort (Sagina procumbens), northern willowherb (Epilobium ciliatum), and common groundsel (Senecio vulgaris) decrease as substrate particle size increases (Wada, 2005).

Numerous studies have shown the benefits of mulch as a weed control tool (Altland et al., 2016; Bartley et al., 2017; Marble et al., 2019; Richardson et al., 2008). In contrast to mulch, which is applied on the substrate surface after planting, a stratified substrate would be part of the growing substrate (crop roots planted into the top stratified layer). This would eliminate mulch application, an extra step in the production process, and possibly reduce labor costs. Additionally, crop plants would be provided with a larger potential rooting volume because containers could be filled completely and there would be no need to leave a 1 - to 3 -inch gap for mulch application. The use of stratified substrate would also eliminate the loss of mulch such as rice (Oryza sativa) hulls, pine (Pinus sp.) bark, and other lighter materials as a result of being blown out of the container or loss caused by container blow-over. Substrate stratification is still a new technique currently being investigated; therefore, its utilization as a weed control tool is unknown. The objective of these experiments was to evaluate the effects of a substrate stratification technique that used more coarse particle pine bark as the top layer and more fine textured bark incorporated with fertilizer as the bottom layer on the growth of common nursery weeds and container ornamental plants.

\section{Materials and methods}

Experiments were conducted at the Mid-Florida Research and Education Center in Apopka, FL, in Nov. 2019, and they were repeated in Feb. 2020. Aged pine bark, originally screened to pass through a 1 -inch screen, was purchased from a local supplier and then further processed by passing the bark through three different soil sieves (0.38-, 0.5-, and 0.75-inch sieves). The substrate (bark) that passed through the soil sieves was collected, and each resulting substrate included all bark particles that were equal to or smaller than each sieve size. The first three substrate treatments included one of the 
three particle sizes $\left(0.38-, 0.5^{-}\right.$, and 0.75 -inch bark) throughout the container and were incorporated with a $17 \mathrm{~N}-2.2 \mathrm{P}-9.1 \mathrm{~K}$ CRF [Osmocote Blend 17-5-11 (8 to 9 months); ICL Specialty Fertilizers, Dublin, $\mathrm{OH}]$ at $35 \mathrm{~g} /$ container throughout (TO) the substrate profile (0.38:TO, 0.5:TO, and 0.75:TO, respectively) according to standard industry practices before planting. Stratified substrate treatments were constructed by having either the 0.5 - or 0.75 -inch prescreened bark mentioned previously as the top substrate with the bottom substrate comprising 0.38 -inch bark. The top substrate $(0.5-$ or 0.75 inch pine bark) was applied at depths of either 2 or 3 inches, resulting in four stratified substrate treatments [abbreviated as screen size $(S)$ in inches for stratification and top depth in inches or 0.5:S:2, 0.5:S:3, 0.75:S:2, and 0.75: $S: 3]$. In all stratified treatments, the CRF was applied at $35 \mathrm{~g} /$ container, but it was only incorporated in the bottom 0.38 -inch substrate layer. An additional treatment was constructed by first screening bark through a 0.75 -inch screen, removing all particles larger than 0.75 inches, and further screening to remove all particles smaller than 0.38 inches. The resulting bark contained no fines $(\mathrm{N} / \mathrm{F})$ and was used as the top substrate at a depth of 2 inches atop the standard 0.38 -inch bark $(0.75: \mathrm{S}: 2: \mathrm{N} / \mathrm{F})$, as described previously. This resulted in a total of eight treatments with equal total substrate volumes and fertilization rates, with the 0.38:TO, 0.5: TO, and 0.75: TO considered industry standard substrates because they comprised particle sizes often selected for use by growers and contained CRF incorporated throughout the substrate profile. However, these pine bark substrates did not contain any amendments such as peatmoss or sand, which are common for the industry (Bilderback et al., 2013).

Particle size and substrate PHYSICAL PROPERTIES. Substrate physical properties and particle size analysis were evaluated for each individual substrate particle size. Particle size analysis was determined by passing $100-\mathrm{g}$ samples of each of the three sizes of pine bark through 12.5-, 9.5-, $6.3-, 2.6-, 1.4-$, and $1.0-\mathrm{mm}$ soil sieves. Particles $\leq 1.0 \mathrm{~mm}$ were collected in a pan. The sieves and pans were shaken for $3 \mathrm{~min}$ using a test sieve shaker (Hogentogler \& Co., Columbia, MD), and the residues of each sieve were collected, weighed, and recorded. Six replicate samples for each substrate were analyzed. Substrate physical properties, including AS, total porosity (TP), container capacity (CC), and bulk density, were determined for six replicates of each substrate using the North Carolina State University porometer method using methods previously described (Fonteno and Bilderback, 1993).

EFFECT OF SUBSTRATE COMPOSITION ON GROWTH OF ORNAMENTAL PLANTS. Uniform liners of ligustrum (Ligustrum japonicum) and blue plumbago (Plumbago auriculata) grown in 2inch plug trays were used to assess the response of common ornamental plants to the stratified substrate treatments. During transplanting, liners were planted using standard planting methods in 1-gal (height, 7.1 inches; diameter, 7.9 inches) nursery containers. In stratified treatments, the roots of the ligustrum and blue plumbago were planted in the top portion of all substrates. After the ornamental plants were transplanted to the aforementioned substrates, all plants were placed on a full sun nursery pad, irrigated 0.5 inches per day via overhead irrigation (Xcel-Wobbler; Senninger Irrigation, Clermont, FL) via two irrigation cycles (7:00 $\mathrm{AM}$ and 2:45 $\mathrm{PM})$, and evaluated for 24 weeks after planting (WAP). Data collected included the plant growth index $[$ (height + width at widest point + perpendicular width $) \div 3]$ measured every 8 WAP and the root and shoot dry weights at the conclusion of the study. The experiment was a completely randomized design with eight single-container replications for each treatment and each ornamental species. The first experimental run was initiated 20 Nov. 2019, and the second was initiated 2 Feb. 2020.

EFFeCt OF SUbSTRATE STRATIFICATION ON WEED GROWTH. To assess weed growth, 25 seeds of bittercress (Cardamine flexuosa) were surfacesown into a separate set (without ornamental plants) of l-gal nursery containers that were filled and fertilized as mentioned previously, placed inside a shade house (60\% ambient light), and irrigated 0.5 inches per day via overhead irrigation (Xcel-Wobbler). Data collection included counts of emerged bittercress (mature and cotyledon stage) at 4 WAP and mature (one to two true leaves) bittercress at 10 WAP.
Shoot dry weight was recorded at the conclusion of the trial (10 WAP). Plants were cut at soil level and placed in a forced-air oven at $60^{\circ} \mathrm{C}$ for $7 \mathrm{~d}$, reaching a constant weight. This study was ended at 10 WAP based on the standard preemergence herbicide application that occurs at 8- to 10-week intervals during summer in Florida. The experiment included a completely randomized design with eight single-container replications per treatment and was repeated.

A separate set of nursery containers were used to evaluate liverwort (Marchantia polymorpha) growth on stratified substrates. Square 0.44-gal (height, 5.25 inches; diameter, 5.25 inches) nursery containers were filled and fertilized with the stratified and industry standard treatments mentioned previously and placed inside the same shadehouse with bittercress and maintained in the same manner. Ten weeks before initiating the experiment and filling containers, four to five pieces of liverwort $\left(\approx 0.5 \mathrm{inch}^{2}\right)$ were transplanted to the surface of the 0.44 gal nursery containers that had been previously filled with a pine bark:peat substrate (80:20 v:v) amended with the CRF via incorporation as described previously. These containers were kept in the same shadehouse as bittercress and irrigated in the same manner. Containers remained in the shadehouse until the surface of the containers was filled with liverwort (no visible substrate on visual inspection). At this time $(\approx 10 \mathrm{WAP})$, these containers were used as inoculum to naturally sporulate the treatments because liverwort can spread asexually through the splashing of gemmae or sexually via airborne spores (Newby et al., 2007). To initiate the experiment, the inoculum containers were placed around each substrate treatment replication at a distance of 0.2 inches so that the experimental containers had an inoculum container on all four sides. Data collected included liverwort surface coverage at 16 WAP. Liverwort coverage was assessed by moving containers to an indoor photo studio and obtaining digital photos of each treatment using a smartphone (iPhone 8 Plus; Apple, Cupertino, CA) from a height of $3 \mathrm{ft}$. Images were cropped using a software program (Microsoft Paint; Microsoft Corp, Redmond, WA) so that only the surface of the substrate and liverwort were visible in the image. 
Liverwort coverage was then analyzed using the ImageJ program (U.S. National Institutes of Health, Bethesda, $\mathrm{MD})$. Image J is a public domain Java image processing program that can perform operations such as edge detection, histogram, and particle analysis that includes sophisticated statistical processing of groups of particles (Abramoff et al., 2004). Liverwort coverage was measured using the color threshold tool, with the color threshold parameters (hue, saturation, and brightness) adjusted to separate liverwort from the substrate. The experiment included a completely randomized design with eight single-container replications per treatment and was repeated.

Statistical analysis. Data were subjected to analysis of variance (ANOVA) using software (JMP Pro version 14; SAS Institute, Cary, NC). Before analysis, all data were inspected to ensure the assumptions of the ANOVA were met. Data were pooled over experimental runs because there was no treatment $\times$ experimental run interactions. Post hoc means comparisons were performed using Tukey's honestly significant difference test, with differences considered significant at $P \leq 0.05$.

\section{Results and discussion}

Particle size and substrate PHYSICAL PROPERTIES. The 0.75 -inch and 0.75 -inch N/F substrate contained the highest percentage of coarse particles, with the 0.75 -inch substrate having a higher percentage of particles larger than $12.5 \mathrm{~cm}$ and the 0.75 -inch $\mathrm{N} / \mathrm{F}$ substrate having a higher percentage of particles captured in the $9.5-\mathrm{mm}$ sieve (Table $\mathrm{l}$ ). The industry standard 0.38 -inch substrate contained $\approx 60 \%$ of $\leq 1.4-\mathrm{mm}$ particles compared with the 0.5 -inch, 0.75 -inch, and 0.75 -inch N/F, which had $31 \%, 21.4 \%$, and $2.6 \%$ of particles in the same size range, respectively.

Despite differences in particle sizes, few differences were observed in $\mathrm{TP}$ and all substrates were generally within or close to the acceptable range of TP [ $50 \%$ to $85 \%$ (Bilderback et al., 2013)] (Table 2). Although all substrates evaluated had more than the $10 \%$ to $30 \%$ recommended AS (i.e., macropores), 0.38-inch bark had lower AS (43.4\%) than the other three substrates evaluated, which were similar, ranging from $53.9 \%$ to $54.1 \%$. All

Table 1. Particle size distribution of a pine bark substrate after sieving through $0.38-, 0.5-$, and 0.75 -inch screens.

\begin{tabular}{lrrrr}
\hline & \multicolumn{4}{c}{ Screen size (inches) } \\
\cline { 2 - 5 } Sieve size $(\mathbf{m m})^{\mathbf{z}}$ & \multicolumn{5}{c}{$\mathbf{0 . 3 8}$} & $\mathbf{0 . 5}$ & $\mathbf{0 . 7 5}$ & $\mathbf{0 . 7 5} \mathbf{N} / \mathbf{F}$ \\
\cline { 2 - 5 } 12.5 & $0.2 \mathrm{c}^{\mathrm{w}}$ & $1.1 \mathrm{bc}$ & $9.0 \mathrm{a}$ & $3.1 \mathrm{~b}$ \\
9.5 & $0.2 \mathrm{c}$ & $2.3 \mathrm{c}$ & $15.8 \mathrm{~b}$ & $71.3 \mathrm{a}$ \\
6.3 & $6.4 \mathrm{c}$ & $23.8 \mathrm{a}$ & $23.6 \mathrm{a}$ & $16.7 \mathrm{~b}$ \\
2.6 & $32.6 \mathrm{~b}$ & $40.9 \mathrm{a}$ & $30.0 \mathrm{~b}$ & $5.2 \mathrm{c}$ \\
1.4 & $21.9 \mathrm{a}$ & $16.8 \mathrm{~b}$ & $11.9 \mathrm{c}$ & $1.0 \mathrm{~d}$ \\
1.0 & $8.2 \mathrm{a}$ & $5.3 \mathrm{~b}$ & $3.6 \mathrm{c}$ & $0.3 \mathrm{~d}$ \\
Pan & $30.4 \mathrm{a}$ & $9.1 \mathrm{~b}$ & $5.9 \mathrm{bc}$ & $1.3 \mathrm{c}$ \\
\hline
\end{tabular}

${ }^{\mathrm{z}}$ Sieve sizes used to determine particle size included 12.5-, 9.5-, 6.3-, 2.6-, 1.4-, and 1.0-mm screens and a pan at the bottom to collect all materials that passed through the smallest sieve. $1 \mathrm{~mm}=0.0394$ inches.

${ }^{y}$ Pine bark was screened through $0.38-, 0.5-$, and 0.75 -inch screens and contained all particles smaller than the screen size with the exception of 0.75 -inch no fines $(\mathrm{N} / \mathrm{F})$, in which only particles retained between 0.75 - and 0.5 -inch screens were retained. 1 inch $=2.54 \mathrm{~cm}$.

${ }^{x}$ Particle size distribution of pine bark screened through $0.38-, 0.5-$, and 0.75 -inch soil sieves. The 0.75 -inch $\mathrm{N} / \mathrm{F}$ pine bark was created by sieving and retaining pine bark that was retained between 0.75 - and 0.5 -inch screens, removing all bark particles $<0.5$ inches. Substrate was air-dried until reaching a constant weight, and then $100-\mathrm{g}(3.53 \mathrm{oz})$ samples were passed through sieves in descending order. Means show weights $(\mathrm{g})$ collected in each sieve $(\mathrm{n}=6)$.

${ }^{\mathrm{w}}$ Means followed by the same letter within a row are not significantly different according to Tukey's honestly significant difference test at $P \leq 0.05$.

substrates with the exception of the 0.38 -inch bark had well below the recommended CC amount of $45 \%$ to $65 \%$. The 0.38 -inch bark used as the bottom substrate had the highest CC amount of any treatment $(42.4 \%)$, followed by the 0.5 - and 0.75 -inch bark, which were similar (33.1\% to $33.8 \%$ ). The 0.75 -inch N/F bark had the lowest CC of any treatment (25.1\%). As particle size increases, CC typically decreases (Gruda and Schnitzler, 2004; Puustjarvi and Robertson, 1975). The 0.75 -inch N/F bark was also constructed specifically to hold less moisture than the other substrates to evaluate its weed suppressive effect. Previous authors have also observed and noted that particle size, the only variable altered in this study, often affects the $\mathrm{CC}$ and $\mathrm{AS}$ ratios but has little effect on TP (Altland et al., 2011; Fields et al., 2021). Overall, the substrate physical property analysis indicated that although all substrates did not differ significantly, the top layers using larger particle sizes did have lower CC and greater AS compared with the 0.38inch substrate used as the bottom layer.

EFFECT OF SUBSTRATE COMPOSITION AND FERTILIZER PLACEMENT ON GROWTH OF LIGUSTRUM AND PLUMbago. At $8 \mathrm{WAP}$, growth indices of ligustrum grown in stratified treatments including $0.5: S: 3,0.75: S: 2$, and $0.75: S: 3$ were smaller compared with the incorporated CRF substrates of 0.38 :
TO and 0.5:TO (Table 3). However, ligustrum grown in $0.5: \mathrm{S}: 2$ or 0.75 : $S: 2: \mathrm{N} / \mathrm{F}$ had sizes similar to those of all incorporated or nonstratified treatments. By 16 WAP, few treatment differences were observed; however, overall, ligustrum in stratified substrates had growth indices similar to those of plants in 0.38:TO. By the conclusion of the experiment at 24 WAP, all ligustrum in stratified substrates had growth indices similar to those of plants in the standard incorporated treatments. Shoot and root dry weights collected at 24 WAP also indicated that although some treatment differences were noted, notably that $0.75: S: 2$ and $0.75: S: 3$ substrates resulted in lower shoot and root weights compared with those of 0.5 :TO, all plants in stratified treatments had similar root and shoot mass compared with those of plants in 0.38:TO. Interestingly, plants in $0.75: S: 2: \mathrm{N} / \mathrm{F}$, which had the lowest water-holding capacity in the top 2 inches (Table 3 ), had shoot and root dry weights similar to or greater than those of all incorporated treatments, even though no fertilizer was incorporated into the top 2 inches of the substrate.

Blue plumbago growth followed a pattern similar to that of ligustrum. Growth index data showed that blue plumbago was initially smaller in stratified substrates including $0.5: \mathrm{S}: 3$ and $0.75: S: 3$ at 8 WAP compared with 
Table 2. Total porosity, air space, container capacity, and bulk density of pine bark sieved through $0.38-$, $0.5-$, and 0.75 inch screens.

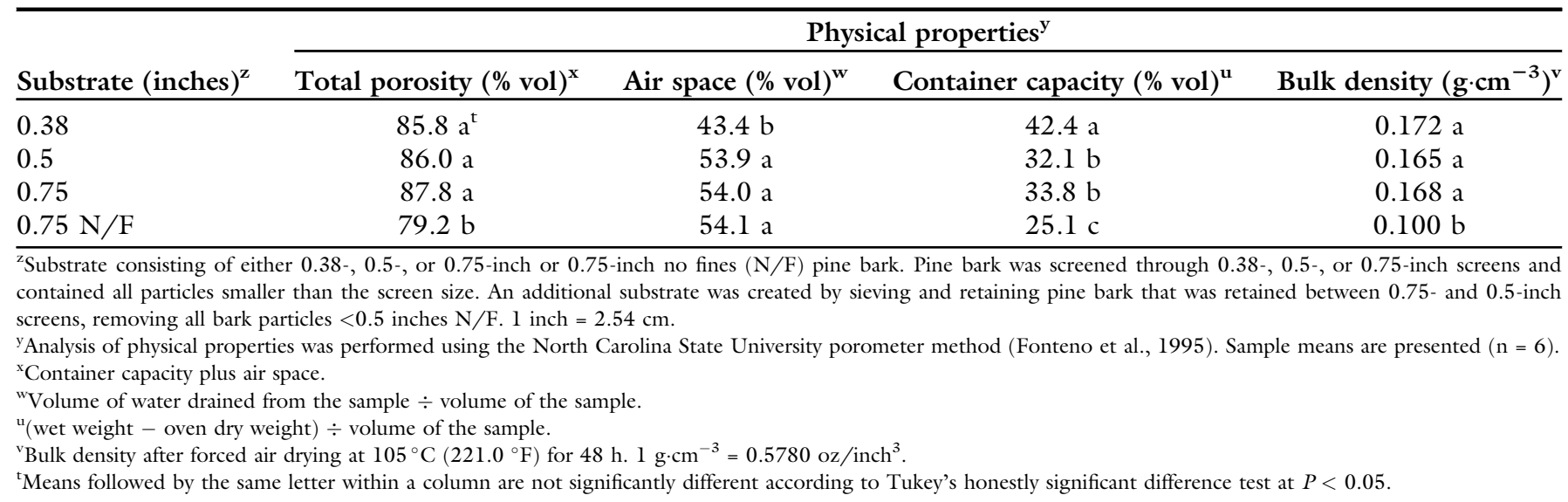

plants in incorporated CRF substrates (Table 4). Also similar to ligustrum, no differences were observed in plumbago growth in any treatment at 16 WAP. By 24 WAP, growth index and shoot and root weight data showed plumbago in stratified treatments had sizes similar to those of plants grown in 0.38: TO and all other incorporated or nonstratified substrates.

Ligustrum and plumbago are both considered relatively drought-tolerant plants with only moderate water requirements, but reduced growth has been observed in containers under various reduced irrigation regimes (Bilderback et al., 2013; Niu et al., 2006; Silva et al., 2012). Stomatal conductance and moisture levels within containers for the study were not assessed. However, because the initial root ball depth of liners was only 2 inches at planting,

plant roots in stratified treatments were likely under at least minor drought stress initially because the entire root ball was planted in a top substrate with lower than recommended water-holding capacity. Paired with low rainfall (Fig. 1), this water stress likely contributed to reduced growth indices early in the experiment for both species, along with potentially lower access to nutrients in comparison with incorporated substrates. As plant roots reached the 0.38 -inch bottom substrate, growth decreases were no longer evident, and all plants reached a marketable size within the same timeframe.

EFFeCT OF SUBSTRATE STRATIFICATION ON BITTERCRESS GERMINATION AND SHOOT BIOMASS AND LIVERWORT ESTABLISHMENT. Bittercress germination was initially highest in $0.38: \mathrm{TO}$ and 0.75:TO substrates, which were similar,

Table 3. Growth index and biomass of container-grown [1 gal $(3.8 \mathrm{~L})]$ ligustrum after growing for 24 weeks in stratified and nonstratified pine bark substrates.

\begin{tabular}{|c|c|c|c|c|c|}
\hline \multirow[b]{2}{*}{ Substrate $^{\mathrm{z}}$} & \multicolumn{3}{|c|}{ Growth index $(\mathrm{cm})^{\mathbf{y}}$} & \multicolumn{2}{|c|}{ Biomass $^{x}$} \\
\hline & 8 WAP & $16 \mathrm{WAP}$ & 24 WAP & Shoot wt (g) & Root wt (g) \\
\hline 0.38:TO & $16.7 \mathrm{a}^{\mathrm{w}}$ & $27.6 \mathrm{abc}$ & $45.8 \mathrm{ab}$ & $58.7 \mathrm{abc}$ & $25.0 \mathrm{abcd}$ \\
\hline 0.5:TO & $17.3 \mathrm{a}$ & 30.1 a & $49.2 \mathrm{ab}$ & $60.8 \mathrm{ab}$ & $26.8 \mathrm{ab}$ \\
\hline 0.75:TO & $16.1 \mathrm{ab}$ & $28.7 \mathrm{abc}$ & $45.6 \mathrm{ab}$ & 58.6 abc & $26.0 \mathrm{abc}$ \\
\hline $0.5: S: 2$ & $17.5 \mathrm{a}$ & $28.8 \mathrm{ab}$ & $45.0 \mathrm{ab}$ & $61.3 \mathrm{ab}$ & $28.2 \mathrm{a}$ \\
\hline $0.5: S: 3$ & $13.7 \mathrm{~b}$ & $24.1 \mathrm{bc}$ & $42.8 \mathrm{ab}$ & $47.7 \mathrm{bc}$ & $20.3 \mathrm{bcd}$ \\
\hline $0.75: S: 2$ & $13.8 \mathrm{~b}$ & $22.8 \mathrm{c}$ & $40.8 \mathrm{~b}$ & $42.4 \mathrm{c}$ & $19.2 \mathrm{~d}$ \\
\hline $0.75: S: 3$ & $13.6 \mathrm{~b}$ & $23.8 \mathrm{bc}$ & $43.1 \mathrm{ab}$ & $44.6 \mathrm{bc}$ & $20.0 \mathrm{~cd}$ \\
\hline $0.75: S: 2: \mathrm{N} / \mathrm{F}$ & $17.8 \mathrm{a}$ & $28.3 \mathrm{abc}$ & $50.8 \mathrm{a}$ & $68.8 \mathrm{a}$ & $27.8 \mathrm{a}$ \\
\hline
\end{tabular}

${ }^{\mathrm{z}}$ Substrate consisted of 0.38 -inch pine bark (PB) throughout $(0.38$ :TO), 0.5-inch PB throughout $(0.5: \mathrm{TO})$, 0.75-inch PB throughout $(0.75: \mathrm{TO}), 0.5$-inch $\mathrm{PB}$ at a depth of 2 inches $(0.5: \mathrm{S}: 2), 0.5$-inch $\mathrm{PB}$ at a depth of 3 inches $(0.5: S: 3), 0.75$-inch $\mathrm{PB}$ at a depth of 2 inches $(0.75: \mathrm{S}: 2), 0.75$-inch $\mathrm{PB}$ at a depth of 3 inches $(0.75: S: 3)$, and 0.75 -inch PB without fines at a depth of 2 inches $(0.75: S: 2: \mathrm{N} / \mathrm{F}) .1$ inch $=2.54 \mathrm{~cm}$.

${ }^{y}$ Growth index was determined by calculating [ (height + width at widest point + perpendicular width $) \div 3$ ] from 0 to 24 weeks of planting (WAP). $1 \mathrm{~cm}=0.3937$ inches.

${ }^{\mathrm{x}}$ Shoot and root dry weights at 24 WAP. $1 \mathrm{~g}=0.0353 \mathrm{oz}$.

${ }^{\mathrm{w}}$ Means $(\mathrm{n}=16)$ followed by the same letter within a column are not significantly different according to Tukey's honestly significant difference test at $P \leq 0.05$. with germination percentages of $\approx 53 \%$ and $45 \%$, respectively (Table 5 ). Although bittercress germination was lower in all of the stratified substrates in comparison with $0.38: \mathrm{TO}$, germination was similar in the 0.5 : TO and 0.75 :TO when compared with most of the stratified substrate treatments. The exception was $0.75: S: 2: \mathrm{N} / \mathrm{F}$, which resulted in a germination rate of only $14 \%$ lower in comparison with all nonstratified treatments. Fewer differences were observed when comparing substrate treatments at 9 WAP; however, in general, bittercress germination continued to be reduced in most of the stratified treatments compared with 0.38:TO.

Shoot dry weight data revealed that there was no difference in the bittercress shoot mass in any of the stratified treatments, and that regardless of depth or particle size, stratification reduced bittercress growth in comparison with nonstratified treatments. The shoot weight reduction was significant, with stratification resulting in an $80 \%$ to $97 \%$ decrease in bittercress biomass. These results are similar to previous findings by Saha et al. (2019), who reported a $90 \%$ reduction in eclipta growth when fertilizer was subdressed. Similarly, Stewart et al. (2018) reported that subdressing to a depth of 1 inch significantly reduced the growth but not the germination of spotted spurge (Euphorbia maculata) and large crabgrass (Digitaria sanguinalis) in comparison with topdressing. Although stratified treatments were not subdressed but used incorporated fertilizer in only the bottom portion of the container, stratification, as implemented in this study, had a similar effect in that the top portion of the container 
Table 4. Growth index and biomass of container-grown [ 1 gal (3.8 L)] blue plumbago after growing for 24 weeks in stratified and nonstratified pine bark substrates.

\begin{tabular}{|c|c|c|c|c|c|}
\hline \multirow[b]{2}{*}{ Substrate $^{z}$} & \multicolumn{3}{|c|}{ Growth index $(\mathrm{cm})^{\mathrm{y}}$} & \multicolumn{2}{|c|}{ Biomass $^{x}$} \\
\hline & 8 WAP & $16 \mathrm{WAP}$ & 24 WAP & Shoot wt (g) & Root wt (g) \\
\hline $0.38: \mathrm{TO}$ & $36.3 \mathrm{ab}^{\mathrm{w}}$ & $53.2 \mathrm{a}$ & $54.9 \mathrm{abc}$ & $44.8 \mathrm{ab}$ & $20.0 \mathrm{ab}$ \\
\hline 0.5:TO & $35.3 \mathrm{ab}$ & $56.1 \mathrm{a}$ & 59.8 a & $47.3 \mathrm{ab}$ & $20.1 \mathrm{ab}$ \\
\hline $0.75: \mathrm{TO}$ & $37.0 \mathrm{ab}$ & $55.3 \mathrm{a}$ & $51.1 \mathrm{bc}$ & $42.7 \mathrm{ab}$ & $20.3 \mathrm{ab}$ \\
\hline $0.5: S: 2$ & $32.0 \mathrm{abc}$ & $51.4 \mathrm{a}$ & $55.8 \mathrm{abc}$ & $46.9 \mathrm{ab}$ & $21.7 \mathrm{a}$ \\
\hline $0.5: S: 3$ & $26.1 \mathrm{c}$ & $52.2 \mathrm{a}$ & $53.8 \mathrm{abc}$ & $39.8 \mathrm{~b}$ & $19.8 \mathrm{ab}$ \\
\hline $0.75: S: 2$ & $30.5 \mathrm{bc}$ & $52.1 \mathrm{a}$ & $54.8 \mathrm{abc}$ & $38.1 \mathrm{~b}$ & $18.7 \mathrm{ab}$ \\
\hline $0.75: S: 3$ & $26.2 \mathrm{c}$ & $49.0 \mathrm{a}$ & $49.1 \mathrm{c}$ & $36.6 \mathrm{~b}$ & $16.4 \mathrm{~b}$ \\
\hline $0.75: S: 2: \mathrm{N} / \mathrm{F}$ & $38.5 \mathrm{a}$ & $51.8 \mathrm{a}$ & $57.5 \mathrm{ab}$ & $53.0 \mathrm{a}$ & $22.4 \mathrm{a}$ \\
\hline
\end{tabular}

${ }^{\mathrm{z}}$ Substrate consisted of 0.38 -inch pine bark (PB) throughout $(0.38: \mathrm{TO}), 0.5$-inch PB throughout $(0.5: \mathrm{TO})$, 0.75 -inch $\mathrm{PB}$ throughout $(0.75: \mathrm{TO}), 0.5$-inch $\mathrm{PB}$ at a depth of 2 inches $(0.5: \mathrm{S}: 2), 0.5$-inch $\mathrm{PB}$ at a depth of 3 inches $(0.5: \mathrm{S}: 3), 0.75$-inch $\mathrm{PB}$ at a depth of 2 inches $(0.75: \mathrm{S}: 2), 0.75$-inch $\mathrm{PB}$ at a depth of 3 inches $(0.75: \mathrm{S}: 3)$, and 0.75 -inch $\mathrm{PB}$ without fines at a depth of 2 inches $(0.75: \mathrm{S}: 2: \mathrm{N} / \mathrm{F}) .1$ inch $=2.54 \mathrm{~cm}$.

${ }^{\mathrm{y}}$ Growth index was determined by calculating [(height + width at widest point + perpendicular width $) \div 3$ ] from 0 to 24 weeks of planting (WAP). $1 \mathrm{~cm}=0.3937$ inches.

${ }^{x}$ Shoot and root dry weights at 24 WAP. $1 \mathrm{~g}=0.0353 \mathrm{oz}$.

${ }^{\mathrm{w}}$ Means $(\mathrm{n}=16)$ followed by the same letter within a column are not significantly different according to Tukey's honestly significant difference test at $P \leq 0.05$.

substrate contained no fertilizer. Although few differences in germination were observed at $9 \mathrm{WAP}$, germination was lower in the stratified substrates at a depth of 2 inches in comparison with the industry standard treatment of 0.38 :TO (Table 5 ). The germinating bittercress seedlings remained small throughout the 10 -week experiment, similar to reports by Khamare et al.
(2020) in which eclipta growth was reduced via subdressing in comparison with topdressing despite few differences in germination.

In addition to the effect of fertilizer placement, substrate stratification using coarser bark as the top portion also likely reduced growth and survival of germinating bittercress seedlings. Currently, the use of mulch is a common nonchemical approach to weed management and has been shown to reduce germination of multiple weed species by serving as a physical barrier and reducing photosynthetically active radiation (Altland et al., 2016; Richardson et al., 2008; Saha et al., 2020). However, these two mechanisms of control are most effective for seeds beneath the mulch (Saha et al., 2020). In nursery production, mulch is often applied at planting to a theoretically weed-free potting substrate. For control of seeds introduced on top of the mulch over time during production, a mulch that drains quickly and has a low volumetric water content is most effective because seeds landing on top of the mulch are not controlled by a barrier or through the elimination of light (Altland et al., 2016; Marble et al., 2019). The stratified substrates used in this study had a lower water-holding capacity than the bottom substrate; therefore, it most likely held less moisture in the top 2- to 3 -inch portion of the container. This potentially contributed to the decreased germination observed in previous stratification treatments with bittercress and creeping woodsorrel (Oxalis corniculata) using rice hull mulch (Altland et al., 2016).

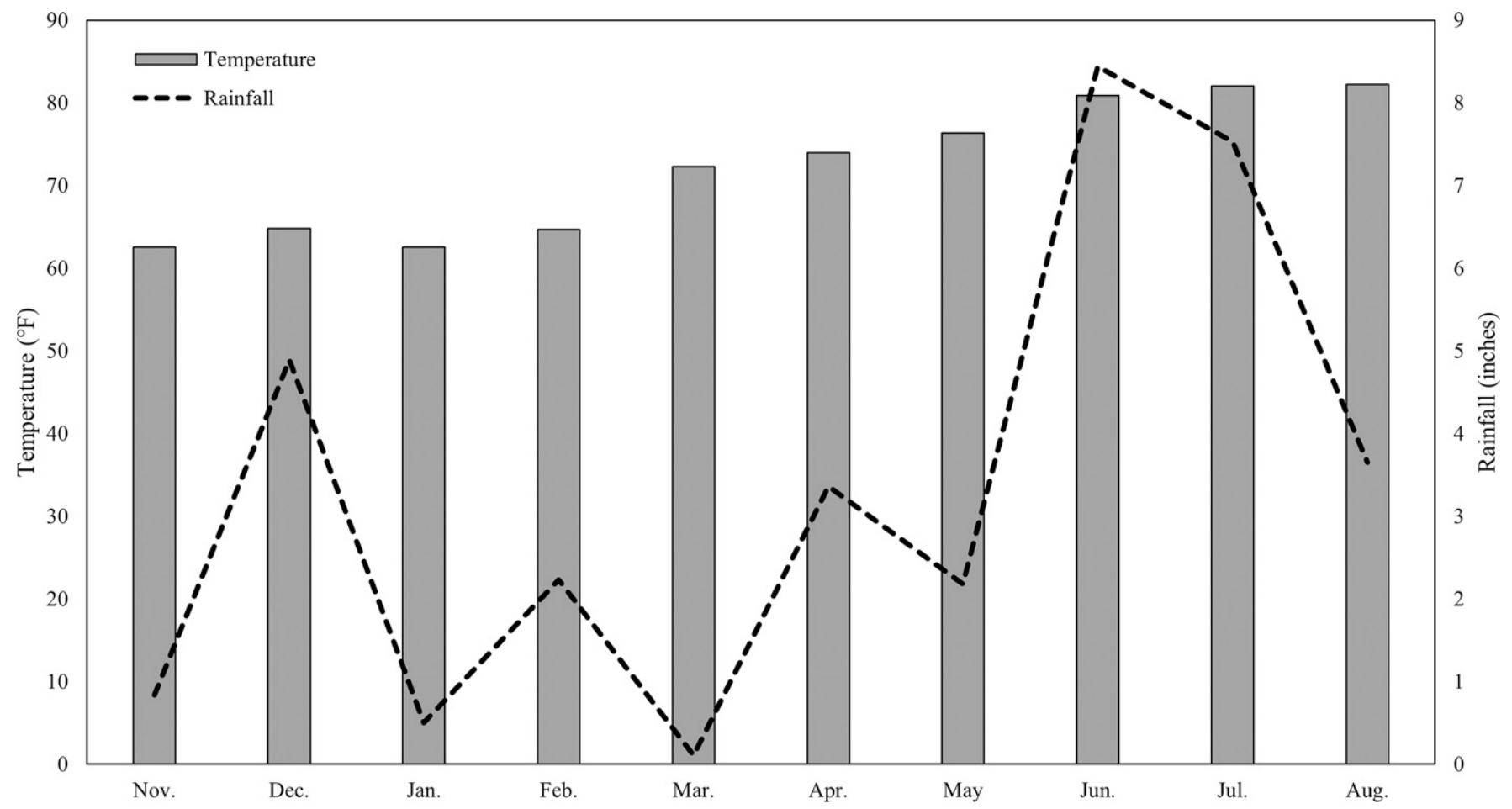

Fig. 1. Average monthly temperature and cumulative rainfall during both experimental runs (Nov. 2019 to July 2020 ). Experiment run 1 was initiated on 20 Nov. 2019, and experimental run 2 was initiated on 2 Feb. 2020, with both experiments being harvested at 24 weeks after planting. 1 inch $=2.54 \mathrm{~cm},\left({ }^{\circ} \mathrm{F}-32\right) \div 1.8={ }^{\circ} \mathrm{C}$. 
Table 5. Effect of substrate stratification and composition on bittercress germination and biomass and growth of liverwort on the substrate surface.

\begin{tabular}{|c|c|c|c|c|}
\hline \multirow[b]{3}{*}{ Substrate $^{\mathrm{z}}$} & \multicolumn{3}{|c|}{ Bittercress } & \multirow{3}{*}{$\begin{array}{c}\text { Liverwort coverage }(\%)^{\mathrm{v}} \\
16 \text { WAP }\end{array}$} \\
\hline & \multicolumn{2}{|c|}{ Germination count $\mathrm{t}^{\mathrm{y}}$} & \multirow{2}{*}{$\begin{array}{c}\text { Biomass }^{\mathrm{x}} \\
\text { Shoot wt (g) }\end{array}$} & \\
\hline & $4 \mathrm{WAP}$ & $9 \mathrm{WAP}$ & & \\
\hline $0.38: \mathrm{TO}$ & $13.2 \mathrm{a}^{\mathrm{v}}$ & $14.0 \mathrm{a}$ & $7.6 \mathrm{a}$ & $61.4 \mathrm{a}$ \\
\hline $0.5: \mathrm{TO}$ & $8.6 \mathrm{bc}$ & $11.9 \mathrm{ab}$ & $5.9 \mathrm{a}$ & $29.3 \mathrm{~b}$ \\
\hline 0.75:TO & $11.3 \mathrm{ab}$ & $11.8 \mathrm{ab}$ & $7.7 \mathrm{a}$ & $18.5 \mathrm{~b}$ \\
\hline $0.5: S: 2$ & $6.9 \mathrm{~cd}$ & $8.7 \mathrm{bc}$ & $1.2 \mathrm{~b}$ & $1.1 \mathrm{c}$ \\
\hline $0.5: S: 3$ & $6.7 \mathrm{~cd}$ & $10.1 \mathrm{abc}$ & $0.5 \mathrm{~b}$ & $0.0 \mathrm{c}$ \\
\hline $0.75: S: 2$ & $6.9 \mathrm{~cd}$ & $8.1 \mathrm{bc}$ & $1.1 \mathrm{~b}$ & $0.1 \mathrm{c}$ \\
\hline $0.75: S: 3$ & $7.9 \mathrm{bc}$ & $10.4 \mathrm{ab}$ & $0.5 \mathrm{~b}$ & $0.0 \mathrm{c}$ \\
\hline $0.75: S: 2: \mathrm{N} / \mathrm{F}$ & $3.4 \mathrm{~d}$ & $6.2 \mathrm{c}$ & $0.2 \mathrm{~b}$ & $0.2 \mathrm{c}$ \\
\hline
\end{tabular}

${ }^{\mathrm{z}}$ Substrate consisted of 0.38 -inch pine bark (PB) throughout $(0.38: \mathrm{TO}), 0.5$-inch PB throughout $(0.5: \mathrm{TO})$, 0.75 -inch $\mathrm{PB}$ throughout $(0.75$ :TO $), 0.5$-inch $\mathrm{PB}$ at a depth of 2 inches $(0.5: \mathrm{S}: 2), 0.5$-inch $\mathrm{PB}$ at a depth of 3 inches $(0.5: \mathrm{S}: 3), 0.75$-inch $\mathrm{PB}$ at a depth of 2 inches $(0.75: \mathrm{S}: 2), 0.75$-inch $\mathrm{PB}$ at a depth of 3 inches $(0.75: S: 3)$, and 0.75 -inch $\mathrm{PB}$ without fines at a depth of 2 inches $(0.75: \mathrm{S}: 2: \mathrm{N} / \mathrm{F}) .1$ inch $=2.54 \mathrm{~cm}$.

${ }^{y}$ Germination count was assessed by surface sowing 25 seeds of bittercress to each container and counting germinated seedlings at 4 weeks and 9 weeks after planting (WAP).

${ }^{x}$ Shoot dry weight at trial conclusion at 10 WAP. $1 \mathrm{~g}=0.0353 \mathrm{oz}$.

${ }^{\mathrm{w}}$ Liverwort coverage was measured by capturing photos at a height of $3 \mathrm{ft}(0.9 \mathrm{~m})$ above the containers and analyzed using the ImageJ software program at $20 \mathrm{WAP}$.

${ }^{\mathrm{v}}$ Means $(\mathrm{n}=16)$ followed by the same letter within a column are not significantly different according to Tukey's honestly significant difference test at $P \leq 0.05$

Liverwort establishment and growth were highest in the 0.38: TO treatment, with $61.4 \%$ surface coverage, followed by 0.5 :TO $(29.3 \%$ coverage $)$ and 0.75 :TO (18.5\% coverage) (Table 5). Growth was negligible in all stratified treatments, with coverage ranging from $0 \%$ to $1 \%$, indicating that stratification would likely be an effective management tool for liverwort because of its sensitivity to environmental conditions (Fig. 2). Liverwort is a bryophyte that spreads in high humidity, high moisture, and lower ultraviolet light levels (Newby et al., 2007). Previous research has shown a high correlation between liverwort growth and irrigation frequency or moisture and high levels of nitrogen (Svenson, 1998). Because liverwort tends to spread under typical nursery production conditions, dibbling fertilizer has been proposed previously as a method of reducing its growth in nursery containers (Altland, 2004). Although container moisture levels were not monitored in these experiments, a physical property analysis indicated that the stratified substrates had a lower water-holding capacity than the industry standard substrate, at least in the top 2 to 3 inches. Additionally, this top stratified layer contained no fertilizer; therefore, thus liverwort was unable to establish on these treatments, at least for a 16-week period.

Results from these experiments indicate that substrate stratification
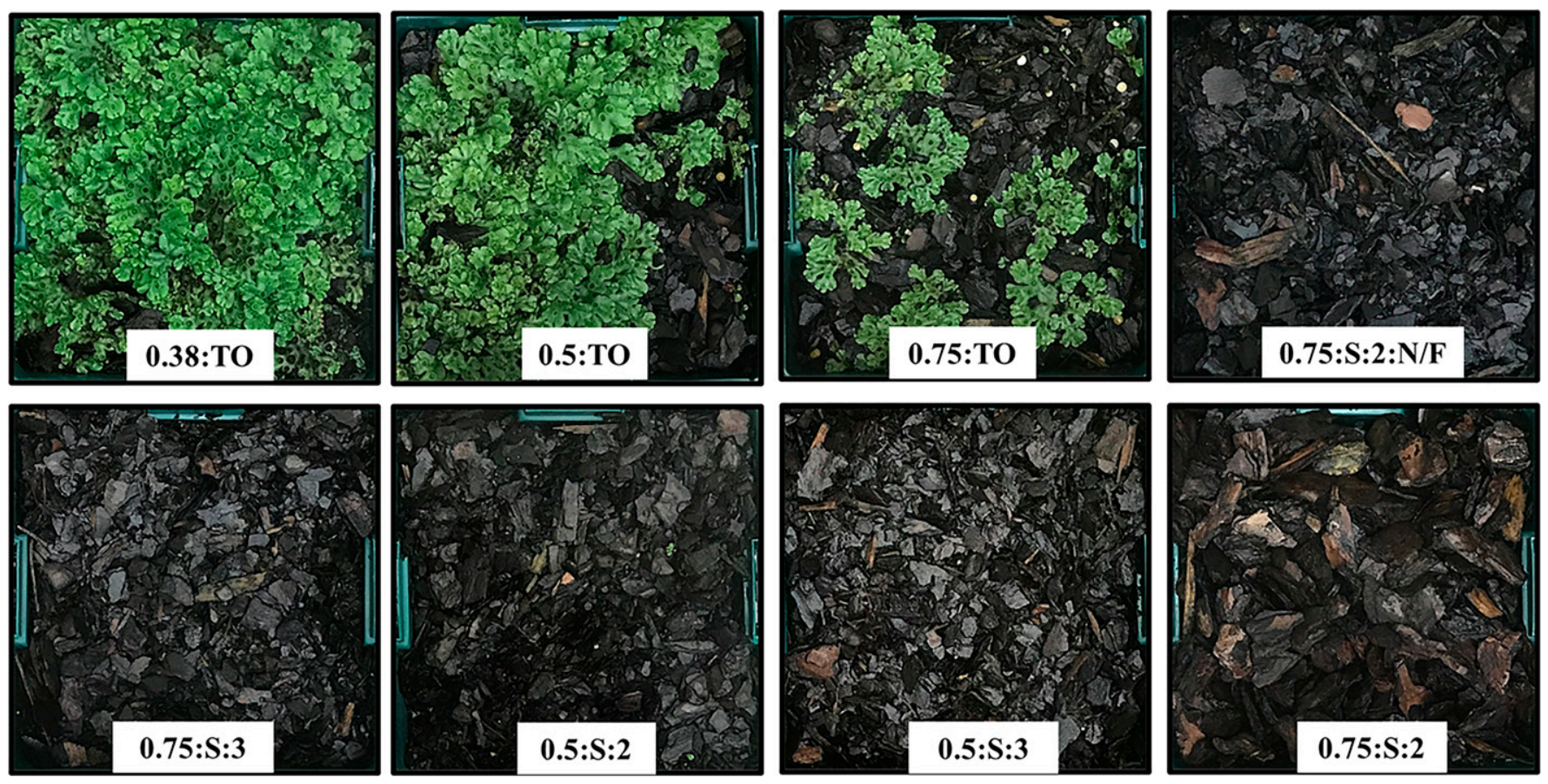

Fig. 2. Liverwort coverage at 16 weeks after planting. 0.38: $\mathrm{TO}=0.38$-inch pine bark $(\mathrm{PB})$ incorporated with controlledrelease fertilizer (CRF) throughout the container; 0.5:TO $=0.5$-inch PB incorporated with CRF throughout the container; 0.75: $\mathrm{TO}=0.75$-inch $\mathrm{PB}$ incorporated with CRF throughout the container; $0.75: \mathrm{S}: 2: \mathrm{N} / \mathrm{F}=0.75$-inch bark with fines removed, applied at a depth of 2 inches with 0.38-inch bark as the bottom substrate with CRF incorporated; 0.5:S:2 = 0.5inch PB as top substrate applied at a depth of 2 inches with 0.38 -inch bark as the bottom substrate with CRF incorporated; 0.5:S:3 = 0.5-inch PB as top substrate applied at a depth of 3 inches with 0.38 -inch bark as the bottom substrate with CRF incorporated; $0.75: \mathrm{S}: 2=0.75$-inch $\mathrm{PB}$ as top substrate applied at a depth of 2 inches with 0.38 -inch bark as the bottom substrate with CRF incorporated, $0.75: \mathrm{S}: 3=0.75$-inch $\mathrm{PB}$ as top substrate applied at a depth of 3 inches with 0.38 -inch bark as the bottom substrate with CRF incorporated; 1 inch $=2.54 \mathrm{~cm}$. 
had no meaningful negative effect on the growth of ligustrum or blue plumbago. Because these experiments were conducted in late fall, with lower temperatures and adequate overhead irrigation, further research is warranted to determine if long-term growth is affected when water stress may be more likely under higher temperature during spring and summer in Florida. Stratification was also effective at reducing the growth of bittercress and liverwort, resulting in reductions in bittercress germination of $40 \%$ to $74 \%$ and in biomass of $84 \%$ to $97 \%$, and by virtually eliminating liverwort growth. It is not clear if fertilizer placement or the use of coarse bark particles as the top substrate had the most significant effect on weed growth. However, based on significant reductions in bittercress biomass despite largely similar bittercress germination rates between industry standard treatments and stratified treatments, fertilizer placement is likely the more important factor for weed suppression. If fertilizer placement was the primary mechanism contributing to weed suppression, then research is needed to determine if the benefit of stratification is negated later in production cycles for longer-term crops when topdressing or fertigation inevitably will be needed after the CRF applied at planting is depleted.

The use of stratified substrates as evaluated in these experiments would offer weed management benefits similar to those of mulch. Moreover, this strategy may provide advantages over the addition of pine bark nuggets, rice hulls, or other mulch materials commonly applied to the surface of nursery containers. The plant liners were planted into this top stratified layer; therefore, the top coarse layer was used as part of the substrate or container volume. As plant roots grew into this stratified layer (Fig. 3), the use of stratification would eliminate the losses associated with mulch, such as rice hulls and other lighter materials being blown out of the containers or pine bark nuggets becoming lost after container blow-over. Availability is also an important factor when selecting a mulch material. Many highly touted mulch materials such as hazelnut shells or cacao bean hulls are seasonal and not readily available in many regions (Altland, 2005). Furthermore, especially in smaller containers, when

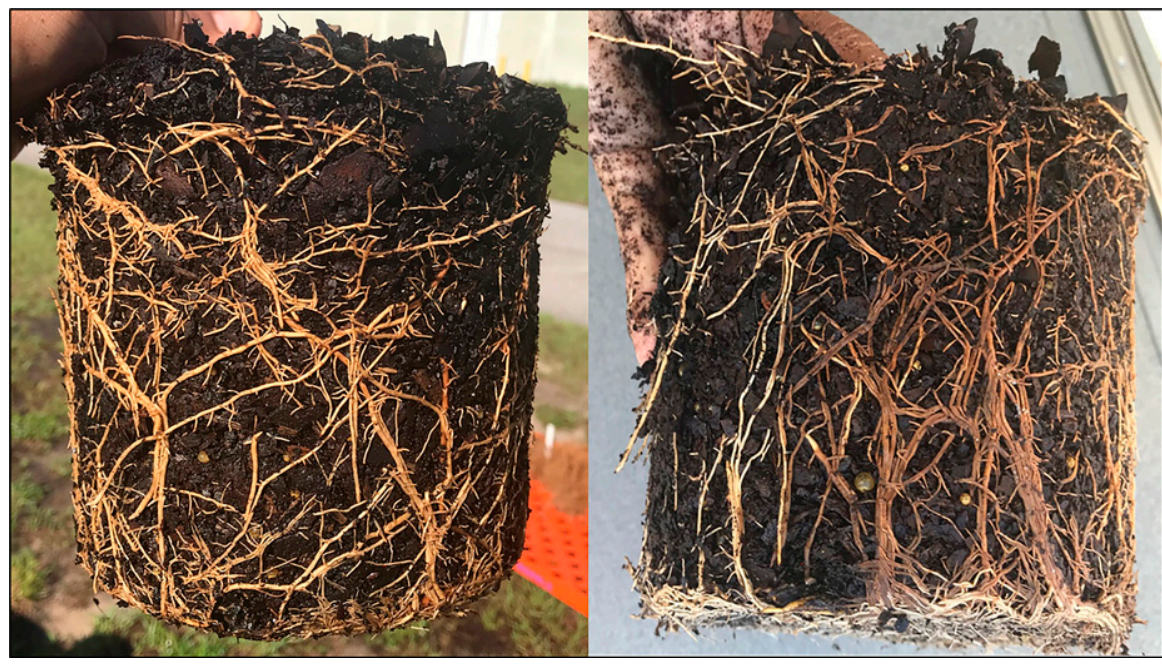

Fig. 3. Example of ligustrum root growth in a stratified substrate. The plant on the left was grown in a substrate constructed with 0.75 -inch pine bark at a depth of 3 inches used as the top substrate and 0.38 -inch pine bark as the bottom substrate with fertilizer only incorporated in the bottom portion $(0.75: S: 3)$. The plant on the right was grown using a 0.38 -inch pine bark throughout the substrate profile with a controlled-release fertilizer incorporated throughout the container at the same rate $(0.38: T O) .1$ inch $=2.54 \mathrm{~cm}$.

applying mulch at a depth suitable for weed control, typically at least 2 inches (Bartley et al., 2017), the potential root volume of the crop plant is reduced by $20 \%$ to $30 \%$ to allow space for mulch application. Stratification could potentially allow for greater root growth area while also providing a weed suppression benefit.

Research has shown that stratifying or layering substrates could provide many benefits regarding reduced fertilizer use, increased water utilization efficiency, improved crop growth (Fields et al., 2021), and, as reported here, reduced weed establishment and growth. It should be noted that the stratification evaluated in the current study was the inverse of the stratification methods developed previously by Fields et al. (2021), whose goal was improving resource efficiency, namely, irrigation and fertilization. Because methods developed by Fields et al. (2021) showed improvements in nutrient and irrigation savings, further research is needed to determine if stratification evaluated for weed management creates negative consequences such as excessive nutrient loss or requires more irrigation early in production cycles. Although crop growth was largely unaffected because the top layer was coarser and, thus, had lower water-holding capacity, any detrimental effects that stratification has on fertilizer release rates after topdressing should be determined as well. On a commercial scale, stratification would also likely require the use of two soil hoppers (with two different substrates) or an additional step of adding the top layer as a final step in the planting process. Although growers have indicated that this practice could be adopted with existing equipment, a cost analysis is needed to determine if the benefits of stratification would outweigh the increased labor costs (Fields et al., 2021).

\section{Literature cited}

Abramoff, M., P. Magalhaes, and S. Ram. 2004. Image processing with ImageJ. 15 Aug. 2021. <http://dspace.library.uu. $\mathrm{nl} /$ handle/1874/204900>.

Altland, J. 2004. Common weeds in Oregon container crops. Oregon State Univ. Ext. Serv. EM 8874. 12 Oct. 2021. $<$ https://catalog.extension.oregonstate. edu/sites/catalog/files/project/pdf/ em8874.pdf $>$.

Altland, J.E. 2005. Weed control in nursery field production. 10 Nov. 2021. <https:// ir.library.oregonstate.edu/concern/open_ educational_resources/sf2685403 $>$.

Altland, J.E., G.B. Fain, and K. Von Arx. 2004. Fertilizer placement and herbicide rate affect weed control and crop growth in containers. J. Environ. Hort. 22:93-99, https://doi.org/10.24266/0738-289822.2.93. 
Altland, J.E., J.K. Boldt, and C.C. Krause. 2016. Rice hull mulch affects germination of bittercress and creeping woodsorrel in container plant culture. Amer. J. Plant Sci. 17(16), https://doi.org/10.4236/ ajps.2016.716207.

Altland, J.E., J.S. Owen, and M.Z. Gabriel. 2011. Influence of pumic and plant roots on substrate physical properties over time. HortTechnology 21:554557, https://doi.org/10.21273/HORT TECH.21.5.554.

Bartley, P.C., G.R. Wehtje, A.M. Murphy, W.G. Foshee, and C.H. Gilliam. 2017. Mulch type and depth influences control of three major weed species in nursery container production. HortTechnology 27:465-471, https://doi.org/ 10.21273/HORTTECH03511-16.

Berchielli-Robertson, D.L., C.H. Gilliam, and D.C. Fare. 1990. Competitive effects of weeds on the growth of container grown plants. HortScience 25:77-79, https://doi.org/10.21273/HORTSCI.25. 1.77 .

Bilderback, T., C. Boyer, M. Chappell, G. Fain, D. Fare, C. Gilliam, B. Jackson, J. Lea-Cox, A. LeBude, and A. Niemiera. 2013. Best management practices guide for producing nursery crops. 3rd ed. Southern Nursery Assoc., Ackworth, GA.

Bir, R.E. and R.H. Zondag. 1986. The great dibble debate: Test results raise more question. Amer. Nurseryman 164:59-64.

Blackshaw, R.E., L.J. Molnar, and H.H. Janzen. 2004. Nitrogen fertilizer timing and application method affect weed growth and competition with spring wheat. Weed Sci. 52:614-622, https://doi.org/10.1614/ WS-03-104R

Case, L.T., H.M. Mathers, and A.F. Senesac. 2005. A review of weed control practices in container nurseries. Hort Technology 15:535-539, https://doi.org/10.21273/ HORTTECH.15.3.0535.

Fain, G.B., P.R. Knight, C.H. Gilliam, and J.W. Olive. 2003. Effect of fertilizer placement on prostrate spurge growth in container production. J. Environ. Hort. 21:177-180, https://doi.org/10.24266/ 0738-2898-21.4.177.

Fields, J.S., J.S. Owen, and J.E. Altland. 2020. Stratified substrates: A media management strategy for increased resource efficiency. HortScience 55:S399-S400 (Abstr.).

Fields, J.S., J.S. Owen, and J.E. Altland. 2021. Substrate stratification: Layering unique substrates within a container increases resource efficiency without impacting growth of shrub rose. Agronomy (Basel) 11:1454, https://doi.org/10.33 90/agronomyl 1081454 .
Fonteno, W.C. and T.E. Bilderback. 1993. Impact of hydrogel on physical properties of coarse-structured horticultural substrates. J. Amer. Soc. Hort. Sci. 118:217-222, https://doi.org/10.21273/JASHS.118. 2.217 .

Fonteno, W.C., C.T. Hardin, and J.P. Brewster. 1995. Procedures for determining physical properties of horticultural substrates using the NCSU porometer., Horticultural Substrates Laboratory, North Carolina State University, Raleigh, NC. 30 Dec. 2021. <https:// projects.ncsu.edu/project/hortsublab/ pdf/porometer_manual.pdf $>$.

Gilliam, C.H., D.C. Fare, and A. Beasley. 1992. Non-target herbicide losses from application of granular Ronstar to container nurseries. J. Environ. Hort. 10:175176, https://doi.org/10.24266/07382898-10.3.175

Gilliam, C.H., W.J. Foster, J.L. Adrain, and R.L. Shumack. 1990. A survey of weed control costs and strategies in container production nurseries. Envrion. Hort. 8: 133-135, https://doi.org/10.24266/07382898-8.3.133.

Gruda, N. and W.H. Schnitzler. 2004. Suitability of wood fiber substrate for production of vegetable transplants. I. Physical properties of wood fiber substrates. Scientia Hort. 100:309-322, https://doi. org/10.1016/j.scienta.2003.10.001.

Harper, J. and R. Benton. 1966. The behavior of seeds in soil. II. The germination of seeds on the surface of a water supplying substrate. J. Ecol. 54:151-166, https://doi.org/10.2307/2257664.

Ingram, D.L., C.R. Hall, and J. Knight. 2016. Carbon footprint and variable costs of production components for a containergrown evergreen shrub using life cycle assessment: An east coast U.S. model. HortScience 51:989-994, https://doi. org/10.21273/HORTSCI.51.8.989.

Ingram, D.L., C.R. Hall, and J. Knight. 2017. Comparison of three production scenarios for Buxus microphylla var. japonica 'Green Beauty' marketed in a No. 3 container on the west coast using life cycle assessment. HortScience 52:357-365, https:// doi.org/10.21273/HORTSCI11596-16.

Keddy, P.A. and P. Constabel. 1986. Germination of ten shoreline plants in relation to seed size, soil particle size and water level: An experimental study. J. Ecol. 74:133-141, https://doi.org/10.2307/ 2260354 .

Khamare, Y., S.C. Marble, and A. Chandler. 2020. Fertilizer placement effects on eclipta (Eclipta prostrata) growth and competition with container-grown ornamentals. Weed Sci. 68:496-502, https://doi.org/10.1017/wsc.2020.44.

Marble, S.C., S.A. Prior, G.B. Runion, H.A. Torbert, C.H. Gilliam, G.B. Fain, J.L. Sibley, and P.R. Knight. 2012. Effects of fertilizer placement on trace gas emissions from nursery container production. HortScience 47:1056-1062, https://doi. org/10.21273/HORTSCI.47.8.1056.

Marble, S.C., S.T. Steed, D. Saha, and Y. Khamare. 2019. On-farm evaluations of wood-derived, waste paper, and plastic mulch materials for weed control in Florida container nurseries. HortTechnology 29:866-873, https://doi.org/10.21273/ HORTTECH04437-19.

Newby, A., J.E. Altland, C.H. Gilliam, and G. Wehtje. 2007. Pre-emergence liverwort control in nursery containers. HortTechnology 17:496-500, https://doi. org/10.21273/HORTTECH.17.4.496.

Niu, G., D.S. Rodriguez, and Y.T. Wang. 2006. Impact of drought and temperature on growth and leaf gas exchange of six bedding plant species under greenhouse conditions. HortScience 41:1408-1411, https://doi.org/10.21273/HORTSCI. 41.6.1408.

Nkebiwe, P.M., M. Weinmann, A. Bar-Tal, and T. Muller. 2016. Fertilizer placement to improve crop nutrient acquisition and yield: A review and meta-analysis. Field Crops Res. 196:389-401, https://doi. org/10.1016/j.fcr.2016.07.018.

Owen, J.S. and J.E. Altland. 2008. Container height and douglas fir bark texture affect substrate physical properties. HortScience 43:505-508, https://doi.org/ 10.21273/HORTSCI.43.2.505.

Poudyal, S. and B.M. Cregg. 2019. Irrigation nursery crops with recycled run-off: A review of potential impact of pesticides on plant growth and physiology. HortTechnology 29:716-729, https://doi.org/ 10.21273/HORTTECH04302-19.

Puustjarvi, V. and R.A. Robertson. 1975. Physical and chemical properties, p. 23-38. In: D.W. Robinson and J.G.D. Lamb (eds.). Peat in horticulture. Academic Press, London, UK.

Richards, D., M. Lane, and D.V. Beardsell. 1986. The influence of particle-size distribution in pine bark:sand:brown coal potting mixes on water supply, aeration, and plant growth. Scientia Hort. 29:1-14, https://doi.org/10.1016/0304-4238(86) 90025-7.

Richardson, B., C.H. Gilliam, G. Fain, and G. Wehtje. 2008. Nursery container weed control with pine bark mininuggets. J. Environ. Hort. 26:144-148, https:// doi.org/10.24266/0738-2898-26.3.144. 
Saha, D., S.C. Marble, N. Torres, and A. Chandler. 2019. Fertilizer placement affects growth and reproduction of three common weed species in pine bark-based soilless nursery substrates. Weed Sci. 67:682-688, https://doi.org/10.1017/ wsc. 2019.49 .

Saha, D., S.C. Marble, B. Pearson, H. Perez, G. MacDonald, and D. Odero. 2020. Emergence of garden spurge (Euphorbia hirta) and large crabgrass (Digitaria sanguinalis) in response to different physical properties and depths of common mulch materials. Weed Technol. 34:172-179, https://doi.org/ 10.1017/wet.2019.88.

Silva, D.D., M.E. Kane, and R.C. Beeson. 2012. Changes in root and shoot growth and biomass partition resulting from different irrigation intervals for Ligustrum japonicum Thunb. HortScience 47:1634-1640,
https://doi.org/10.21273/HORTSCI. 47.11.1634.

Simpson, C.V., C.H. Gilliam, J.E. Altland, G.R. Wehtje, and J.L. Sibley. 2002. Postemergence oxalis control in container grown crops. Southern Nursery Assoc. Res. Conf. 47:376-379.

Stewart, C., S.C. Marble, B. Jackson, B. Pearson, and C. Wilson. 2017. Impact of container nursery production practices on weed growth and herbicide performance. HortScience 52:1593-1600, https://doi.org/10.21273/HORTSCI 12241-17.

Stewart, C., S.C. Marble, B.E. Jackson, B.J. Pearson, and P.C. Wilson. 2018. Effects of three fertilization methods on weed growth and herbicide performance in soilless nursery substrates. J. Environ. Hort. 36:133-139, https://doi.org/ 10.24266/0738-2898-36.4.133.
Svenson, S.E. 1998. Suppression of liverworth growth in containers using irrigation, mulches, fertilizers, and herbicides. HortScience 33:485 (Abstr.).

U.S. Department of Agriculture, National Agricultural Statistics Service. 2019. 2019 Census of horticulture specialties. 20 Sept. 2021. <http://www.agcensus.usda.gov/ Publications/2019>.

Wada, S. 2005. Nursery container weeds response to modification of substrate $\mathrm{pH}$, substrate particle size and applied nitrogen form. MS Thesis, Oregon State Univ., Corvallis.

Wilson, P.C., T. Whitwell, and M.B. Riley. 1995. Effects of ground cover and formulation on herbicides in runoff water from miniature nursery sites. Weed Sci. 43:671-677, https://doi.org/10.1017/ S0043174500081819. 